\title{
Predictions in ungauged basins - where do we stand?
}

\author{
Günter Blöschl \\ Institute of Hydraulic Engineering and Water Resources Management, Vienna University of Technology, \\ Karlsplatz 13/222, 1040 Vienna, Austria \\ Correspondence to: Günter Blöschl (bloeschl@hydro.tuwien.ac.at) \\ Published: 12 May 2016
}

\begin{abstract}
The spatial dimensions of water management heavily rely on accurate hydrological estimates in the landscape. This has exactly been the focus of the Predictions in Ungauged Basins (PUB) initiative of the IAHS. The initiative has significantly advanced the science by furthering process understanding and estimation methods, and by synthesising the knowledge across processes, places and scales. Ongoing research on PUB is increasingly treating water management as an intrinsic part of the hydrological cycle and is developing processes understanding and methods to account for the feedbacks between humans and water in the landscape.
\end{abstract}

\section{The Prediction in Ungauged Basins (PUB) problem}

Accurate estimates of stream runoff and other hydrologic quantities are needed for numerous purposes of water resources planning and management, in particular if one is interested in the spatial dimension. The most accurate way of obtaining such estimates at any one location is to measure them for an extended period of time. However, often this is not possible for financial or logistic reasons, or simply because one is interested in the future evolution of the hydrological variables. The alternative therefore is to estimate them from measurements at other locations in the region and transfer them, in some way, by modelling methods.

Methods for estimating runoff at ungauged locations such as the Rational Method and the index-flood method have been in practical use for a long time. However, there are a range of other hydrological characteristics for which estimates are needed in ungauged catchments, including low flows, rainfall and evaporation. Also, for many purposes, empirical methods do not suffice and process understanding needs to be invoked in order to make predictions that are reliable for a diverse set of hydrological conditions.

\section{Best practice recommendations for predicting runoff in ungauged basins}

The international research on predictions in ungauged basins has received a major impetus through a research initiative of the International Association of Hydrological Sciences (IAHS). The initiative, known as Predictions in Ungauged Basins (PUB), was started in 2003 (Sivapalan et al., 2003) and intended to advance the research on the topic around the globe. The varied and extensive outcome of the initiative suggests that this has indeed been accomplished (see, e.g., Hrachowitz et al., 2013).

One of the achievements of the initiative was a synthesis of methods that before had been treated in a fragmented way (Blöschl et al., 2013). The synthesis proceeded along the dimensions of processes, places and scales. The synthesis across processes involves a consistent and coherent treatment of annual runoff, seasonal runoff, the flow duration curve, floods, low flows and entire hydrographs. The synthesis across places is built on the notion of similarity and draws together experience and data from numerous catchments in a region and from around the world. The synthesis across scales involves a balanced view of both upscaling methods based on laboratory equations (such as distributed models) and lumped catchment scale models (such as regional statistical relationships).

The synthesis report of the initiative concluded with best practice recommendations for predicting runoff in ungauged 
Table 1. Summary of best practice recommendations (from Takeuchi et al., 2013).

\begin{tabular}{|c|c|}
\hline Step & Recommendation \\
\hline Step 1: Read the landscape & $\begin{array}{l}\text { Go out to your catchment, look around, what does the landscape tell you, create a photo } \\
\text { documentation, look at the hydrogeology, ask people about previous events, obtain global, } \\
\text { regional and local data, map hydraulic structures and other modifications. } \\
\text { If possible, install a stream gauge. }\end{array}$ \\
\hline Step 2: Runoff signatures and processes & $\begin{array}{l}\text { Analyse all runoff signatures in nearby catchments to get understanding of hydrology of the } \\
\text { catchment beyond the signature of interest. Runoff signatures include annual runoff, } \\
\text { seasonal runoff, flow duration curve, low flows, floods, and hydrographs. }\end{array}$ \\
\hline Step 3: Process similarity and grouping & $\begin{array}{l}\text { On the basis of the first two steps and process similarity measures find similar gauged } \\
\text { catchments to assist in predicting runoff in the ungauged basin (grouping of landscape } \\
\text { units and catchments). The similarity can be based on short term and co-evolutionary processes. }\end{array}$ \\
\hline Step 4: Model & $\begin{array}{l}\text { Build statistical and/or process based model for the signature of interest; regionalise the } \\
\text { parameters from similar catchments, making advantage of a priori information, dynamic proxy } \\
\text { data and any other information on processes, including from the other signatures; account for } \\
\text { correlations along the stream network. There is always more information than the } \\
\text { hydrograph - use it. }\end{array}$ \\
\hline Step 5: Interpretation & $\begin{array}{l}\text { Interpret the parameters of the model hydrologically and justify their values against what was } \\
\text { learned during field trip and other data, to improve parameter choice and uncertainty estimation. } \\
\text { Parameters are, e.g., regression coefficients and runoff model parameters. }\end{array}$ \\
\hline Step 6: Uncertainty & $\begin{array}{l}\text { Assess uncertainty of predicted runoff by combining error propagation methods, regional cross } \\
\text { validation and hydrological interpretation against the backdrop of the uncertainty to be expected } \\
\text { from comparative hydrology (Level } 1 \text { and } 2 \text { ). We now have a prediction of runoff signature } \\
\text { including understanding of its credibility. }\end{array}$ \\
\hline All steps & $\begin{array}{l}\text { Communicate all of this in a way that it contributes to the global and national body of } \\
\text { knowledge in hydrology, especially process knowledge. }\end{array}$ \\
\hline
\end{tabular}

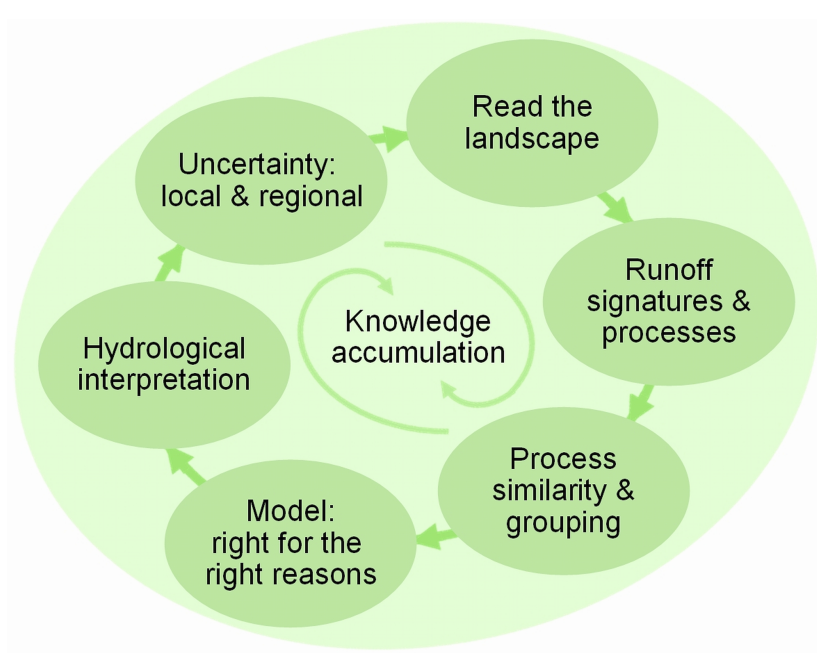

Figure 1. Best practice recommendations for predicting runoff in ungauged basins (from Takeuchi et al., 2013).

basins (see Fig 1 and Table 1). In addition to this general pattern, the exact method of estimating runoff in any one case, of course, depends on many factors, including data availability, nature of the catchment and the nature of the estimation problem.

\section{Recent developments}

Research on PUB has continued to flourish in the most recent years, both from a theoretical perspective and for assisting the spatial dimensions of water management. For example, flood risk management has recently evolved from a focus on individual flood protection structures to a more integrated approach at the river basin scale that considers a diversity of management measures and changes in the flood risk over time (e.g. Merz et al., 2014). New methodological developments have been aligned with the requirements of the Flood Risk Directive regarding hazard mapping, large scale interactions of floods, residual risk (flood prevention); retaining water in the landscape, linear protection measures, flood retention (flood mitigation); public participation, outreach and education (awareness); flood warning, emergency plans (preparation); and assessment of flood damage, event documentation (recovery) (Blöschl et al., 2015).

With all these new developments it is increasingly becoming clear that it is essential to treat water management as an intrinsic part of the hydrological cycle. This means it no longer suffices to make estimates for pristine catchments and correct for any human effects once the estimates have been obtained. Instead, the processes understanding and methods 
Table 2. Seven steps of framing and modeling hydrological vs coupled dynamic environmental vs socio-hydrological processes (shortened from Sivapalan and Blöschl, 2015).

\begin{tabular}{ll}
\hline Step & Recommendation \\
\hline Step 1: Phenomenon, domain, scale & $\begin{array}{l}\text { Specify phenomenon, domain, study period, purpose of modeling. } \\
\text { The phenomena are often defined through narratives }\end{array}$ \\
\hline Step 2: Perceptual model & $\begin{array}{l}\text { Causal loop diagram to conceptualise process interactions, assisted by } \\
\text { narratives of phenomena to visualize alternative hypotheses }\end{array}$ \\
\hline Step 3: Choice of state variables & $\begin{array}{l}\text { Small number of variables usually of advantage. Variables should be measurable. } \\
\text { Values are a key state variable for a long term treatment }\end{array}$ \\
\hline Step 4: Causal factors that affect state variables & $\begin{array}{l}\text { Causal factors can be state variables or external forcing. Known balance equations } \\
\text { (e.g., financial budget) may assist in choice of factors (and therefore coupling) }\end{array}$ \\
\hline Step 5: Functional relationships for step 4 & $\begin{array}{l}\text { Use of local data may require upscaling. Scaling analysis to help identify fast and slow } \\
\text { state variables. Guidance by socio-economic data (e.g., surveys, censoring) and narratives }\end{array}$ \\
\hline Step 6: Parameter estimation & $\begin{array}{l}\text { Disassemble model into components and estimate parameters separately. Re-assemble } \\
\text { model and estimate feedback parameters against emergent phenomena. Evaluate effect } \\
\text { of model parameters on path dependence and lock-ins of model dynamics }\end{array}$ \\
\hline Step 7: Model validation and uncertainty & $\begin{array}{l}\text { Test component models against different streams of data. If phenomena are repeatable } \\
\text { in space or time, test model against similar situations at different places or in different } \\
\text { time periods. If phenomena are not repeatable, no full validation is possible. Sources of } \\
\text { uncertainty may include non-optimum behaviour of humans. }\end{array}$ \\
\hline
\end{tabular}

need to account for the feedbacks between humans and water in the landscape.

This brings to the fore the time dependency of hydrological variables in the landscape. From a spatial problem one then progresses to a spatio-temporal problem. While much of the spatial PUB work, such as the best practice recommendations, are still valid under such a framework, an extension is required to allow for the temporal dynamics of the system. One appealing approach of doing this is to frame the coupled human-nature system as a dynamical system, characterized by interactions of fast and slow time scales and feedbacks between environmental and social processes. These interactions give rise to emergent phenomena such as:

- Critical transitions, path dependence, multiple equilibria, lock-in situations

- Levee effect, adaptation to change, system collapse due to resource depletion

Di Baldassarre et al. (2015) discuss such emergent phenomena for the specific case of floods.

When framing such processes there is almost always the issue of data scarcity, i.e. this is a genuine predictions in ungauged basin (PUB) problem. While there are numerous similarities with the PUB problem there also additional challenges due to the coupled nature of the processes involved and the specific characteristics of social processes, such as context dependence. Sivapalan and Blöschl (2015) proposed seven steps of framing such coupled processes that account for the specific characteristics (Table 2). An important part of the framing is to take advantage of narratives representing the phenomena of human-water interactions. The phenomena may be generic (any of the broad class of process causalities that manifest in several places, e.g., the levee effect, irrigation efficiency paradox), or they could be place based, reflecting the unique characteristics of a place and its water history.

Depending on whether one is interested in place based or generic phenomena, the model complexity may vary from complex, comprehensive models that account for much spatial and process detail to stylized models that are typically lumped and much more parsimonious in terms of their process representation. Sivapalan and Blöschl (2015) highlighted the pros and cons of the different model types. The comprehensive models have the advantage that they can be readily applied to real world management problems in specific places, but the modeling effort may be larger and it may be very difficult to specify all the required parameters in a realistic way. Also, because of the complexity, it is very challenging to understand the overall system behavior for different parameter combinations and to reveal long-term, largescale phenomena. On the other hand, the stylized models have the advantage of transparency and ease of use. It is possible to fully explore their dynamic behavior space for all parameter combinations, including any emergent behavior and the borders between stability and instability. This can provide guidance for decision making but at a strategic level. Their disadvantage is the difficulty of estimating realistic parameters since they represent aggregate behavior that cannot directly be translated into local scale decisions.

Developing these dynamic models in a spatial context bears a lot of resemblance with the research in the PUB ini- 
tiative of IAHS, however, this time framed in a dynamic way. The research also provides important opportunities to assist the spatial dimensions of water resource management from a practical perspective, including

- facilitating stakeholder participation,

- helping decision-makers through the generation and assessment of alternative futures, and

- learning from the experiences of other similar places, and move towards generalizations beyond individual case studies (Sivapalan and Blöschl, 2015).

The new IAHS initiative on change in hydrology and society, known as Panta Rhei (Montanari et al., 2013), is geared towards a better understanding of the changing dynamics of the water cycle related to changing human systems. Clearly, there are important synergies between the research on predictions in ungauged basins and Panta Rhei in addressing new exiting science questions from a spatio-temporal perspective in order to further the science of hydrology.

\section{References}

Blöschl, G., Sivapalan, M., Wagener, T., Viglione, A., and Savenije, H. H. G. (Eds.): Runoff Prediction in Ungauged Basins - Synthesis across Processes, Places and Scales, Cambridge University Press, Cambridge, UK, 465 pp., 2013.

Blöschl, G., Horváth, Z., Kiss, A., Komma, J., Nester, T., Perdigão, R. A. P., Viglione, A., and Waser, J.: Neue Methoden für das Hochwasserrisikomanagement (New methods for flood risk management), Österreichische Ingenieur- und ArchitektenZeitschrift (ÖIAZ), 160, 15-27, 2015.

Di Baldassarre, G., Viglione, A., Carr, G., Kuil, L., Yan, K., Brandimarte, L., and Blöschl, G.: Debates - Perspectives on socio-hydrology: Capturing feedbacks between physical and social processes, Water Resour. Res., 51, 4770-4781, doi:10.1002/2014WR016416, 2015.

Hrachowitz, M., Savenije, H. H. G., Blöschl, G., McDonnell, J. J., Sivapalan, M., Pomeroy, J. W., Arheimer, B., Blume, T., Clark, M. P., Ehret, U., Fenicia, F., Freer, J. E., Gelfan, A., Gupta, H. V., Hughes, D. A., Hut, R. W., Montanari, A., Pande, S., Tetzlaff, D., Troch, P. A., Uhlenbrook, S., Wagener, T., Winsemius, H. C., Woods, R. A., Zehe, E., and Cudennec, C.: A decade of Predictions in Ungauged Basins (PUB) - a review, Hydrol. Sci. J., 58, 1198-1255, doi:10.1080/02626667.2013.803183, 2013.
Merz, B., Aerts, J., Arnbjerg-Nielsen, K., Baldi, M., Becker, A., Bichet, A., Blöschl, G., Bouwer, L. M., Brauer, A., Cioffi, F., Delgado, J. M., Gocht, M., Guzzetti, F., Harrigan, S., Hirschboeck, K., Kilsby, C., Kron, W., Kwon, H.-H., Lall, U., Merz, R., Nissen, K., Salvatti, P., Swierczynski, T., Ulbrich, U., Viglione, A., Ward, P. J., Weiler, M., Wilhelm, B., and Nied, M.: Floods and climate: emerging perspectives for flood risk assessment and management, Nat. Hazards Earth Syst. Sci., 14, 19211942, doi:10.5194/nhess-14-1921-2014, 2014.

Montanari, A., Young, G., Savenije, H. H. G., Hughes, D., Wagener, T., Ren, L. L., Koutsoyiannis, D., Cudennec, C., Grimaldi, S., Blöschl, G., Sivapalan, M., Beven, K., Gupta, H., Arheimer, B., Huang, Y., Schumann, A., Post, D., Srinivasan, V., Boegh, E., Hubert, P., Harman, C., Thompson, S., Rogger, M., Hipsey, M., Toth, E., Viglione, A., Di Baldassarre, G., Schaefli, B., McMillan, H., Schymanski, S. J., Characklis, G., Yu, B., Pang, Z., and Belyaev, V.: Panta Rhei - Everything Flows": Change in hydrology and society - The IAHS Scientific Decade 2013-2022, Hydrol. Sci. J., 58, 1256-1275, doi:10.1080/02626667.2013.809088, 2013.

Sivapalan, M. and Blöschl, G.: Time scale interactions and the coevolution of humans and water, Water Resour. Res., 51, 69887022, doi:10.1002/2015WR017896, 2015.

Sivapalan, M., Takeuchi, K., Franks, S. W., Gupta, V. K., Karambiri, H., Lakshmi, V., Liang, X., McDonnell, J. J., Mendiondo, E. M., O'Connell, P. E., Oki, T., Pomeroy, J. W., Schertzer, D., Uhlenbrook, S., and Zehe, E.: IAHS Decade on Predictions in Ungauged Basins (PUB), 2003-2012: Shaping an exciting future for the hydrological sciences, Hydrol. Sci. J., 48, 857-880, 2003.

Takeuchi, K., Blöschl, G., Savenije, H. H. G., Schaake, J. C., Sivapalan, M., Viglione, A., Wagener, T., and Young, G.: Recommendations, Chapter 13, in: Runoff Prediction in Ungauged Basins - Synthesis across Processes, Places and Scales, edited by: Blöschl, G., Sivapalan, M., Wagener, T., Viglione, A., and Savenije, H., Cambridge University Press, Cambridge, UK, 384 387, 2013. 